\title{
Conceptual design of a thermal weed control machine
}

\author{
Roger Toscan Spagnolo ${ }^{1^{*}}$ (iD André Oldoni ${ }^{2}$ iD Tiago Vega Custódio ${ }^{3}$ \\ Ângelo Vieira dos Reis ${ }^{4}$ \\ Antônio Lilles Tavares Machado ${ }^{4}$ iD \\ ${ }^{1}$ Centro de Engenharias, Universidade Federal de Pelotas (UFPEL), 96010-020, Pelotas, RS, Brasil. E-mail: roger.toscan@gmail.com. \\ ${ }^{*}$ Corresponding author. \\ ${ }^{2}$ Instituto Federal Sul Rio Grandense (IFSul), Pelotas, RS, Brasil. \\ ${ }^{3}$ Programa de Pós-graduação em Sistemas de Produção Agrícola Familiar (PPGSPAF), Universidade Federal de Pelotas (UFPEL), Pelotas, \\ RS, Brasil. \\ ${ }^{4}$ Departamento de Engenharia Rural (DER), Universidade Federal de Pelotas (UFPEL), Pelotas, RS, Brasil.
}

ABSTRACT: The great difficulty for family farmers who produce food organically is the control of weeds without using chemical products. One possibility for the management is the use of heat in the sense of coagulating the protoplasm in leaves and stem cells. The present research aimed toconceptual design a mechanized system for weeds control through the use of heat focusing on familiar farmers who produce food organically. In this study, we used a product development methodology which can be divided into different stages that are composed of several tasks. As a result of the use of such methodology, six concepts of heat transfer machines were developed. After the application of selection tools, two concepts were chosen for the optimization process, and then the one considered ideal to meet the needs of farmers was selected.

Key words: product development, agricultural machinery, organic production.

Projeto conceitual de máquina para o controle de plantas daninhas pela aplicação de calor

RESUMO: A grande dificuldade dos agricultores familiares que produzem alimentos de forma orgânica é o controle de plantas daninhas sem a aplicação de produtos químicos. Uma possibilidade para o manejo é a utilização de calor, no sentido de coagular o protoplasma em células das folhas e do caule. O objetivo do presente trabalho foi projetar uma concepção de um sistema mecanizado para o controle das plantas daninhas por meio da utilização de calor, tendo como público alvo agricultores familiares que produzem de forma orgânica. Para a realização do trabalho foi empregada metodologia de desenvolvimento de produtos, a qual pode ser dividida em diferentes fases, que são compostas por diversas tarefas. Como resultado da aplicação da metodologia obteve-se seis concepções de máquinas aplicadoras de calor. Após aplicação de ferramentas de seleção foram escolhidas duas concepções para o processo de otimização, obtendo-se posteriormente aquela considerada ideal para atender as necessidades dos agricultores.

Palavras-chave: desenvolvimento de produto, máquinas agrícolas, produção orgânica.

\section{INTRODUCTION}

One of the difficulties for family farmers that produce organic food is the management of weeds without the use of chemical products or soil tillage. These farmers usually have small areas and make use of manual methods of weeding (weed removal) to control weed growth which are cumbersome and time-consuming. The main crops produced included corn, vegetables, and sweet potatoes. The monthly income of these families is considered low (SPAGNOLO et al., 2017).
According to DATTA \& KNEZEVIC (2013), thermal control is an acceptable and feasible option for weed management in organic and conventional production systems. This is an old technique which was widely used prior to the emergence of agrochemicals, several models were developed and tested commercially between 1940 and 1975. Recently, due to the growing demand for organic products, there has been a search for alternatives to the use of chemical control of weeds. Thermal weed control has been one of the techniques used by some researchers (SNIAUKA \& POCIUS, 
2008; KANG, 2001; ULLOA et al., 2010; ULLOA et al., 2012; KNEZEVIC et al., 2013; STEPANOVIC et al., 2015; KANELLOU et al., 2017).

However, these studies did not contemplate the design of equipment from the use of systematic design methodologies. According to ROMANO et al. (2005), agricultural machinery design may be divided into four stages as follows: informational design, conceptual design, embodiment design, and detailed design. Documents generated in each of these stages included design specifications, product concept, final layout, and documentation.

Research focused on family farmers in which tools in the design and development of products have been carried out by a number of researchers including VIANNA et al. (2014) who developed a seed meter with horizontal plate and double outlets, STEFANELLO et al. (2014) who obtained the functional structure of a hand-operated seeder, CUSTÓDIO et al. (2018) who determined the functional structure of a fertilizer spreader for lowpower tractors, and SPAGNOLO et al. (2018) that determined the specifications for the design of a heat application mechanism.

With the use of systematized design methodology, the present study aimed to create a concept of a mechanized system for weed management using thermal control (heat) in organic family farming.

\section{MATERIALS AND METHODS}

In the present study, we used the product development methodology except for the conceptual design stage. The starting point for this study was the project specifications defined in the informational design stage by SPAGNOLO et al. (2018). Based on this information, we were able to establish the scope of the problem and the overall function of the product.

After determining the overall function of the machine which consisted of a block diagram of the technical system with inputs and outputs of material, energy and signal, we divided it into sub-functions called partial functions and then into elementary functions as proposed by PAHL et al. (2005) and BACK et al. (2008).

For each elementary function, we searched for at least one solution based on a literature review, analysis of similar systems in the market or patented systems, and application of the brainstorming method as proposed by BACK et al. (2008). Solutions were annotated and then designed using SolidWorks software adding the morphological matrix in which the principles of solution were combined in order to generate at least one design for each functional structure.

For the selection of the most promising concept, two selection techniques were applied successively: feasibility judgment and pass/fail test. In the judgment of viability, it was noted on the basis of the experience of the team members whether each individual conception was "feasible", "conditionally feasible" or "not feasible", and the reasons for the decision was recorded. In the pass/fail test, the concepts were individually compared with questions arising from the clients' needs as presented by SPAGNOLO et al. (2018). The questions were answered as "yes" or "possibly" (pass) or "no" (fail). The concept that had more positive responses than negative responses was chosen.

A new concept was born as the positive characteristics of the selected concepts in the previous stage were combined. The solution principles of the discarded concepts in the previous stage that considered promising were also included taking into account the observations made by the team members.

\section{RESULTS AND DISCUSSIONS}

The scope of the problem was defined as: to develop a mechanized system that allows cellular destruction (derangement) of weeds without damaging the implanted culture. Therefore, it was determined that the designed mechanism should be safe and money-saving and should accurately apply heat to weeds in diverse cultures. It is therefore possible to declare the global function as applying heat to weeds.

According to STEFANELLO et al. (2014), based on the global function of the system, different structures can be generated by the multiplicity of some functions and distinct flows of material, energy, and signals. As a result, four different functional structures (A, B, C, and D) were created. One of these items (functional structure $\mathrm{B}$ ) is represented in figure 1 and is composed of eight partial functions. It was noted that functions F4 (gas storage), F5 (gas dosing), F6 (applying heat), and F7 (isolating heat) are subdivided and form a total of 15 elementary functions.

Function F1 (coupling to the traction source) has mechanical energy inputs to aid in coupling to the traction source and kinetic energy to the displacement of the machine. This mechanism should allow the use of a tractor with a power of less than $55 \mathrm{~kW}$. Therefore, the design of the three- 


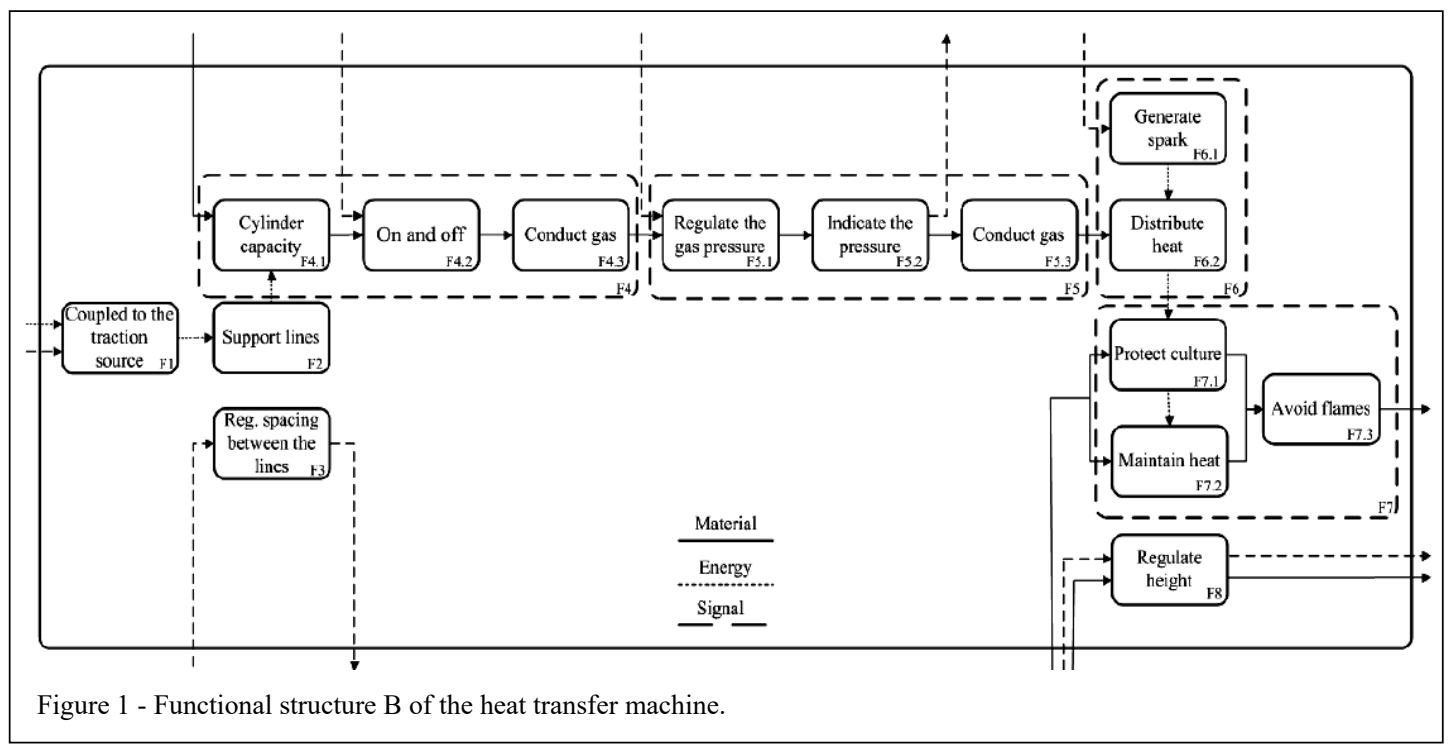

point coupling should be in accordance with NBR 730 in order to fit into categories 1 and 2. The function "support lines" (F2) refers to the support mechanism for the connection of the lines since the "regular spacing between the lines" function (F3) determines that the machine should present a variation between a line as well as the junction of two lines allowing the control of weeds in different crops according to project specifications defined by SPAGNOLO et al. (2018).

In the gas storage function (F4), it was necessary to increase the "on and off" (F4.2), "conduct gas" (F4.3), and the "cylinder capacity" sub-functions (F4.1). This LPG (Liquefied Petroleum Gas) packaging should allow the use of a cylinder with different capacities (P13, P20, P45 or P90) according to the user choice as the capacity of the smaller cylinder increases the unit cost of the gas.

KANG (2001) and ULLOA et al. (2012) describe that the higher the application rate of LPG the greater is the level of weed control. ULLOA et al. (2010) used doses between $40 \mathrm{~kg}$ and $86 \mathrm{~kg} \mathrm{ha}^{-1}$ of LPG in order control $90 \%$ of the plants. This dose of LPG varies according to the species and plants development stage (KNEZEVIC et al., 2013).

Similarly, function F5 was subdivided into 3 sub-functions. It is known that in order dosing gas (F5), the user should operate and control (adjust) the machine in order to regulate the gas pressure (F5.1). The machine should indicate the pressure (F5.2) to the user by means of a sound or visual signal and conduct the gas (F5.3) with pressure measured to the mechanisms involved in distributing heat (F6.2). However, in order to perform the F6 function "apply heat" (which is the most important function of the machine), this machine should generate a spark (F6.1) for the LPG to become thermal energy.

Application of heat only is insufficient. The crop should not be damaged, and the machine should be the most efficient possible. According to STEPANOVIC et al. (2015), heat treatment may cause lesions to the plants of the implanted culture according to its stage of development. However, this should be avoided.

In order to minimize possible injuries to the crop, the "heat insulation" function (F7) was developed which provides at least one mechanism that is capable of protecting the culture (F7.1), maintaining the heat (F7.2) and avoiding flames (F7.3) as well. KANG (2001) created a prototype to combat weeds and used a $1.4 \mathrm{~m}$ long structure installed at the end of the heat transfer nozzles in order to improve heat retention and increase the time of exposure of the plants to heat.

The prototype developed by KANG (2001) had six LPG gas cylinders, five heat exchanger nozzles spaced approximately $24 \mathrm{~cm}$ apart, a pressure gauge, a valve and pressure control valve, and a mechanism to control the height of the nozzles according to the variations of the relief. Application of heat and temperature of flames are determinant in LPG consumption and in the control rate of plants (ULLOA et al., 2012). Therefore, the regular function 
height (F8) was created. The F8 predicts the use of a mechanism that allows the uniform application of heat regardless of the variation of the terrain topography.

According to VIANNA et al. (2014), possible solution principles of use in the design of a product may be considered after the analysis of the functions involved in the process of using this product. In the present study, the morphological matrix method was used. With the combination of at least one of the principles of solution for each function, it was possible to make six concepts as shown in figure 2.
In order to select the most promising concept that would be optimized at a later stage, concepts were analyzed by the project team. This team ruled out the use of Concept 1 since in this concept the positioning of the gas tank near the heat application line would increase the risk of heating of the cylinders; and therefore, compromises the operation safety.

The other five concepts were submitted to a selection process. The first technique used for selection was the viability judgment with which two concepts were considered unfeasible. Concept 2

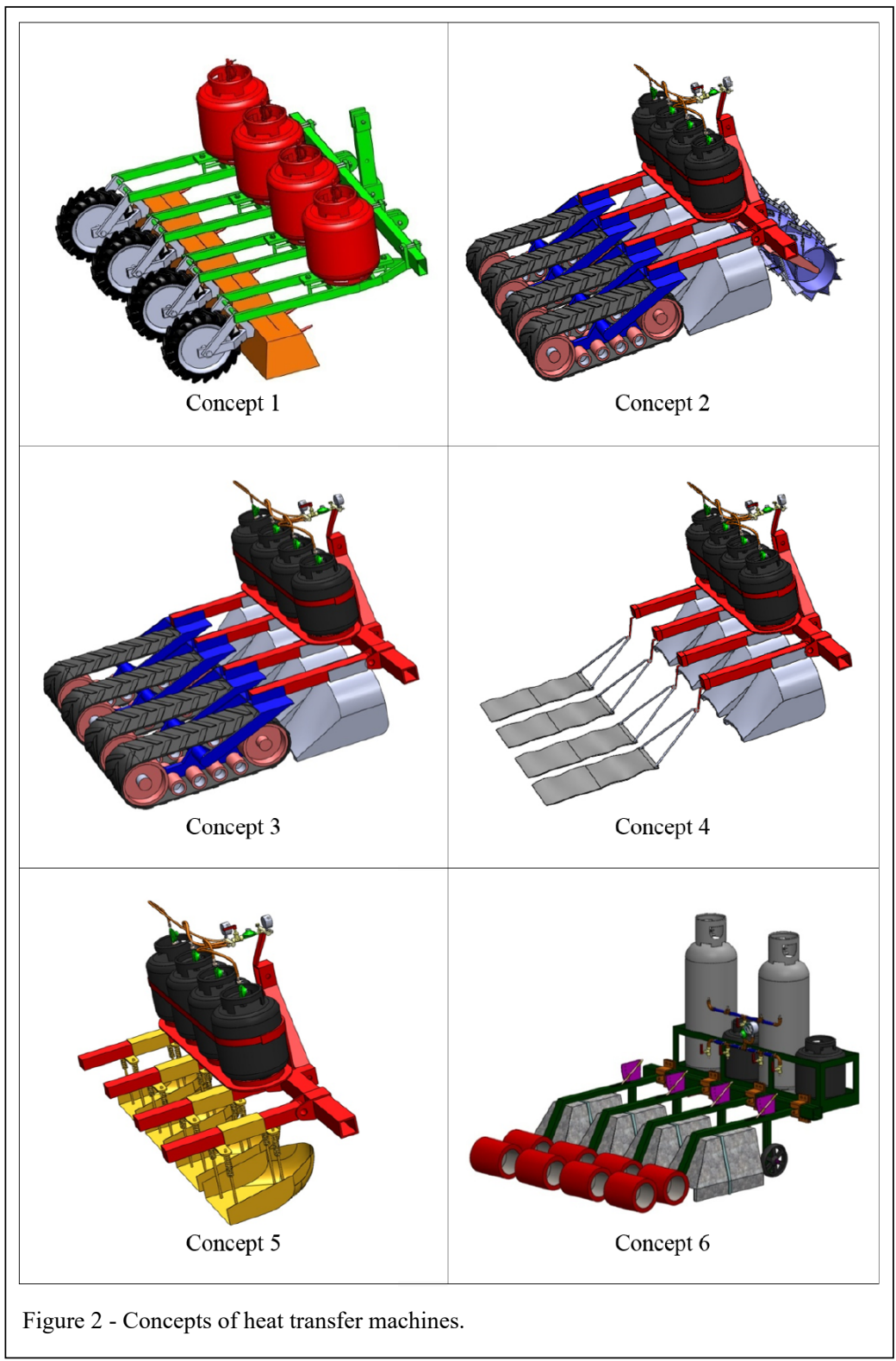

Ciência Rural, v.49, n.3, 2019. 
predicted the use of a roller-knife whereas in Concept 5 the indirect application of heat was expected. In the case of Concept 2, the application of heat after the plant was cut was considered an unnecessary activity since the heat can reach only the part of the plant which is already dead and not its stem which favors this plant regrowth.

Concept 5 was discarded because the application of indirect heat would cause greater energy loss as a result would increase gas consumption. In addition, obstacles such as stones and amount of weeds present in the crop would compromise the machine performance and affects the machine lifetime. Another factor considered for the non-use of Concept 5 is related to the reports published by SNIAUKA \& POCIUS (2008), which describe that the impact of the flames applied directly and instantaneously on the ground is minimal. According to these authors, flames with an intensity of $1100 \mathrm{kcal} \mathrm{ha}^{-1}$ reduced the microflora of the soil by $19 \%$ when analyzed in their profile up to $5 \mathrm{~mm}$ of depth. Soil temperature at this depth increased by $3^{\circ} \mathrm{C}$. The $10 \mathrm{~mm}$ depth increased by $1^{\circ} \mathrm{C}$, and at $20 \mathrm{~mm}$ depth there was no change in soil temperature.

The second technique used to select the concept was the pass/fail test. Fifteen questions were prepared based on the clients' needs, obtained in the informational design stage. Concept 3 was eliminated after the application of the pass/ fail technique as negative aspects were observed regarding the complexity of its design, difficulty in the purchase of parts, high cost for manufacturing, and use of a mat to fight off flames, which could hamper maneuvering at the head of the crop due to weight and length. Therefore, Concepts 4 and 6 were selected for the optimization process. At this stage, the combination and optimization of mechanisms considered promising to form the Optimized Concept (Figure 3) was performed.

To generate the Optimized Concept (Figure 3) some changes were made in Concept 6. The manner of fixing the cylinders was modified making it simpler with a location on the tool chassis such as the one in Concept 4. In order to fix the lines, a pantographic system was defined with the aid of a wheel to follow the irregularities of the terrain and was no longer articulated as in Concept 6 .

The heat application chamber of the Concept 6 was also optimized which was modified to be easier to manufacture. The simplest flamefighting mechanism would be that of Concept 4 .

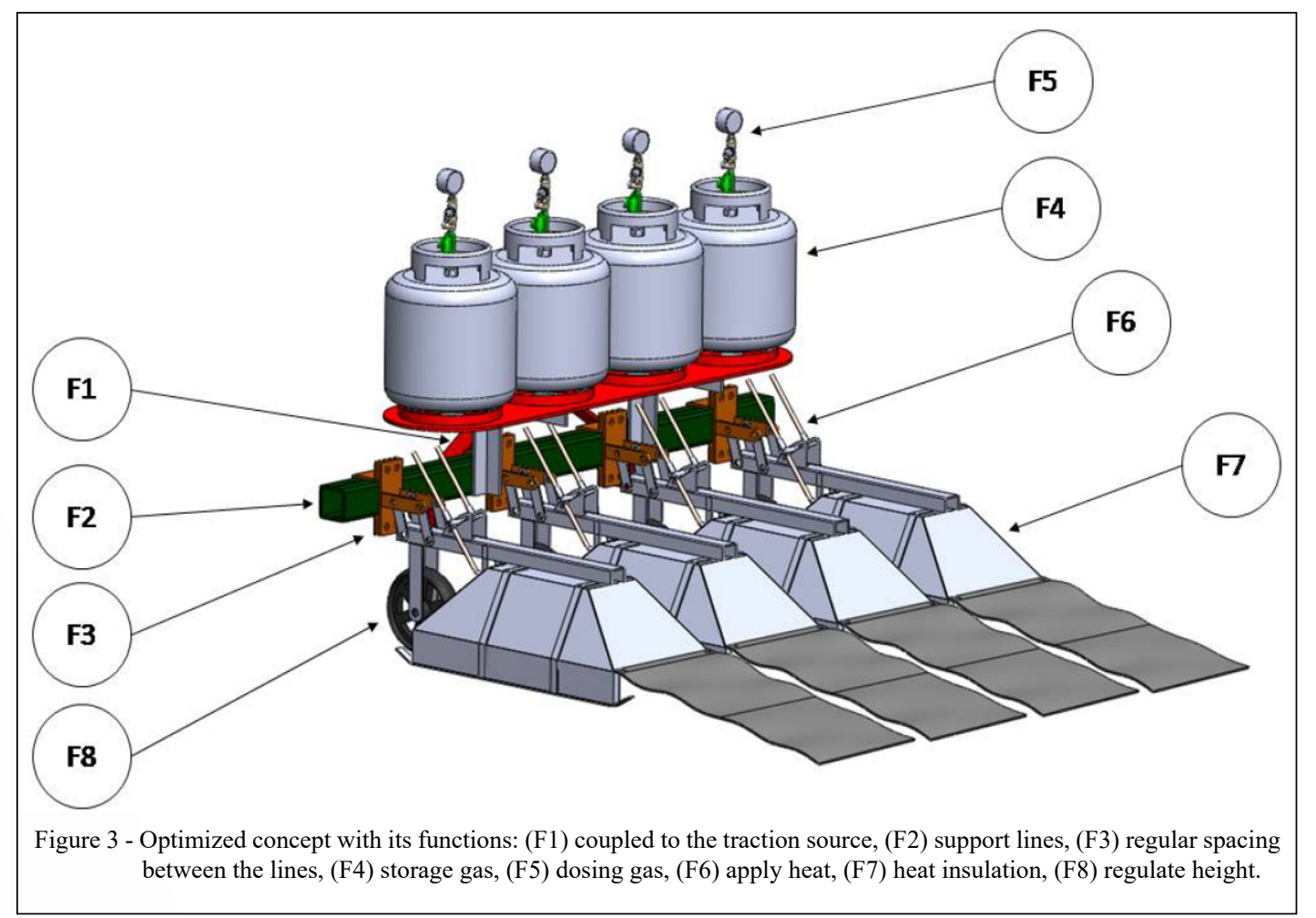

Ciência Rural, v.49, n.3, 2019. 
But instead of being suspended in the Optimized Concept (Figure 3), it became attached to the back of the heat-applying chamber.

With the assistance of the Optimized Concept, it will be possible to move on to the next phase of the project which is the preparation of the embodiment design, i.e., the design of components and product design (prototype) continuing the systematized design as described by ROMANO et al. (2005).

Therefore, it is believed that the mechanized system generated from the Optimized Concept will be able to provide the cellular destruction (derangement) of the weeds without damaging the implanted crop meeting the needs of the organic family farmers cited by SPAGNOLO et al. (2017), mainly with regard to efficiency, possible use in several crops, and the low cost of acquisition. In conclusion, based the Optimized Concept (Figure 3), we were able to design and construct a machine prototype for field tests in order to examine the efficacy of the general operation of this machine.

\section{CONCLUSION}

In the present study, we were able to use a systematized design methodology in order to create four different functional structures and six concepts of mechanized system for the control of weeds by the application of heat focused on organic family agriculture.

The optimized concept generated by the improvement of the two conceptions initially selected allows us to continue the design process successfully.

\section{ACKNOWLEDGEMENTS}

This study was financed in part by the Coordenação de Aperfeiçoamento de Pessoal de Nível Superior - Brasil (CAPES) - Finance Code 001.

\section{DECLARATION OF CONFLICTING INTERESTS}

The authors declare no conflict of interest. The founding sponsors had no role in the design of the study; in the collection, analyses, or interpretation of data; in the writing of the manuscript, and in the decision to publish the results.

\section{REFERENCES}

BACK, N. et al. Projeto integrado de produtos: planejamento, concepção e modelagem. Barueri, SP: Manole, 2008. 648p.

CUSTÓDIO, T. V. et al. Functional structure of a bedshaper and fertilizer depositor for low power tractors. Engenharia na
Agricultura, v.26, n.2, p.133-139, 2018. Available from: <http:// www.seer.ufv.br/seer/index.php/reveng/article/view/827/pdf>. Accessed: Apr. 30, 2018.

DATTA, A.; KNEZEVIC, S. Z. Flaming as an alternative weed control method for conventional and organic agronomic crop production systems: a review. Advances in Agronomy, v.118, p.399-428, 2013. Available from: <https://doi.org/10.1016/B9780-12-405942-9.00006-2>. Accessed: Apr. 21, 2018. doi: 10.1016/ B978-0-12-405942-9.00006-2.

KANELLOU, E. et al. Flame weeding at Archaeological Sites of the Mediterranean Region. Weed Science Society of America, v.31 n.3, p.396-403, 2017. Available from: <http://www.bioone. org/doi/full/10.1017/wet.2016.31>. Accessed: May, 08, 2018. doi: 10.1017/wet.2016.31.

KANG, W. S. Development of a flame weeder. American Society of Agricultural Engineers, v.44, p.1065-1070, 2001. Available from: <http://dx.doi.org/10.13031/2013.6428>. Accessed: Apr. 19, 2018. doi: $10.13031 / 2013.6428$.

KNEZEVIC, S. Z. et al. Soybean yield and yield components as influenced by the single and repeated flaming. Crop Protection, v.50, p.1-5, 2013. Available from: <http://dx.doi.org/10.1016/j. cropro.2013.03.014>. Accessed: Apr. 20, 2018. doi: 10.1016/j. cropro.2013.03.014

PAHL, G.; BEITZ, W.; FELDHUSEN, J.; GROTE, K-H. Projeto na engenharia: fundamentos do desenvolvimento eficaz de produtos, métodos e aplicações, São Paulo: Edgard Blucher, 2005. 411p.

ROMANO, L. N. et al. An introduction to the reference model for the agricultural machinery development process. Product: Management \& Development, v.3, n.2, p.109-132, 2005. Available from: $<$ http://citeseerx.ist.psu.edu/viewdoc/download?doi=10.1.1.4 71.853\&rep $=$ rep1\&type $=$ pdf $>$. Accessed: Apr. 20, 2018.

SNIAUKA, P.; POCIUS, A. Thermal weed control in strawberry. Agronomy Research, v.6, p.359-366, 2008. Available from: $<$ http://agronomy.emu.ee/vol06Spec/p6S21.pdf $>$. Accessed: Apr. 20, 2018.

SPAGNOLO, R. T. et al. Organic production: properties characterization and mechanical situation on weed control. Engenharia na Agricultura, v.25, n.6, p. 517-525, 2017. Available from: <http://www.seer.ufv.br/seer/index.php/reveng/ article/view/796/pdf >. Accessed: Apr. 30, 2018.doi: 10.13083/ reveng.v25i6.796.

SPAGNOLO, R. T. et al. Design specifications of a heat applicator weed controller device for family farms. Ciência Rural, v.48 n.2, e20170243, 2018. Available from: <https://dx.doi. org/10.1590/0103-8478cr20170243>. Accessed: Apr. 22, 2018. doi: $10.1590 / 0103-8478 \mathrm{cr} 20170243$.

STEFANELLO, G. et al. Functional structure of a human-powered seeder. Ciência Rural, v.44, n.9, p.1583-1588, set, 2014. Available from: <http://dx.doi.org/10.1590/0103-8478cr20130020>. Accessed: Apr. 30, 2018. doi: 10.1590/0103-8478cr20130020.

STEPANOVIC, S. et al. The effectiveness of flame weeding and cultivation on weed control, yield and yield components of organic soybean as influenced by manure application. Renewable Agriculture and Food Systems, v.31 n.4, p. 288-299, Jun., 
2015. Available from: <https://www.cambridge.org/core/services/ aop-cambridge-core/content/view/638EFD6F9C4EBA82E52B 188C218FB960/S1742170515000216a.pdf/effectiveness_of_ flame weeding and cultivation on weed control yield and yield_components_of_organic_soybean_as_influenced_by manure_application.p.pdf $>$. Accessed: May, $0 \overline{8}, 2 \overline{0} 18$. doi: $10 . \overline{1017 /}$ S1742170515000216.

ULLOA, S. M. et al. Tolerance of selected weed species to broadcast flaming at different growth stages. Crop Protection, v.29, p.1381-1388, 2010. Available from: <https://doi.org/10.1016/j.cropro.2010.07.017>. Accessed: Apr. 20, 2018. doi: 10.1016/j.cropro.2010.07.017.
ULLOA, S. M. et al. Weed control and crop tolerance to propane flaming as influenced by the time of day. Crop Protection, v.31, p.1-7, 2012. Available from: <https://doi.org/10.1016/j. cropro.2011.09.005>. Accessed: Apr. 19, 2018. doi: 10.1016/j. cropro.2011.09.005.

VIANNA, L. R. et al. Development of a horizontal plate meter with double seed outlets. Revista Brasileira de Engenharia Agrícola e Ambiental, v.18, n.10, p.1086-1091, Oct. 2014. Available from: $<$ http://www.scielo.br/scielo.php?script=sci_arttext\&pid=S141543662014001000015\&lng=pt\&nrm=iso>. Accessed: Apr. 30, 2018. doi: 10.1590/1807-1929. 